\title{
RETAIL FORMAT SELECTION: OCCUPANCY COST AND PROFITABILITY
}

\author{
Amanda Duvenhage* \\ University of Johannesburg
}

Received: November 2016

\author{
André Kruger* \\ University of Johannesburg
}

Accepted: January 2017

\begin{abstract}
Retail property management teams neglect the influence of occupancy costs and the resultant profitability of different retail formats when assessing their decision to expand. The aim of this research was to provide an easy-to-understand profitability equation for shopping centres and standalone outlets to guide retail property management teams in their decision-making process. A quantitative study, using secondary data obtained from a single retailing group and analysed using a simplified profitability formula, was conducted. The research endeavoured to determine the influence of rent on profitability to provide financial guidance to property management teams when benchmarking different retail formats. This included an investigation into the relationship between size and rent value besides the comparison of the profitability of different retail formats. Although financial considerations form an important part of the decision-making process, retail property management teams should continue to combine the results of financial benchmarking with consumer preferences to achieve optimum results.
\end{abstract}

Keywords

Retail format selection, retail property management, occupancy cost, profitability, retail formats

*Ms A Duvenhage is a master's student in the Department of Finance and Investment Management at the University of Johannesburg, South Africa.

\#Mr A Kruger is a lecturer in the Department of Finance and Investment Management at the University of Johannesburg, South Africa. [akruger@uj.ac.za] 


\section{INTRODUCTION}

The arrival on our shores of Wal-Mart, the world's largest retailer, has challenged the local retail industry and placed much needed emphasis on the future of retail formats in South Africa (Alexander, 2012). Nonetheless, Wal-Mart is starting to move to smaller formats, i.e. smaller premises, in order to reach different markets in areas that have limited trading space (Deal, 2012). Smaller formats are increasingly seen as cost-effective innovations, providing flexibility to retailers to change their offering, displays and layout and marketing materials quickly and inexpensively to adapt to a changing consumer environment (Navarro \& Ripsam, 2007). As a result, the increase in popular retail formats is adding pressure to property management teams who have to make recommendations to their operating partners. These property management teams have to be well informed about the preferences and needs of the consumers with regard to the specific market in which they operate, as well as the financial influence that these formats might have on the bottom line of these retail businesses.

In order to understand the possible financial impact of a chosen format on the business, the costs associated with the tenancy of the space need to be established. Understanding the costs for the different retail formats would allow the property teams to determine the affordability of each format and incorporate the findings into their recommendations regarding the choice of a specific format. Because both tenants and landlords strive to maximise profits, property teams will be better equipped during lease negotiation procedures if they appreciate the determinants of rent and other occupancy costs.

To provide for both their utilitarian and social needs, retail stores are under constant pressure to evolve and in the process enhance their market position (Hui, Yiu \& Yau, 2006). As a result of the role played by demand and supply, the play-off between what consumers require and the shopping product that retailers offer will always remain fundamental to the industry (Hui, Yiu \& Yau, 2006).

The retail formats studied during our research were shopping centres and stand-alone outlets and the data collected was accordingly grouped into these two retail formats. The possibility existed that when grouping the data of the different centre types into a single 'shopping centre' format, the results for the individual stores would be distorted and the results for individual stores could therefore not be assumed.

The grouping also necessitated splitting occupancy costs between rent and other occupancy costs in order to meet the objectives of the study. Only basic rent was used as 'rent' due to the manner in which the expenses are grouped in the data obtained. This limited the outcome to the basis of 'basic rent' only. Other occupancy costs were restricted to those of the specific retailer. Other retailers could argue that a different group of expenses are classified as 'other occupancy expenses'. This argument should be taken into account should the results be applied to a broader population.

Underlying the costs discussed above are the structure of the lease and the crucial role that the determinants of rent play in the benchmarking of strategies when comparing retail formats, as occupancy costs are influenced by the choice of the retail format. Not only does the inclusion of certain occupancy costs differ between retail formats, but certain costs also vary between tenants in the same retail format. Therefore, the goal of the retailer remains to identify and monitor such costs in order to create value for the company and ultimately the shareholders.

The problem is that management neglects the impact of occupancy costs and the resultant profitability of different retail formats when assessing their decision to expand. According to 
Jennings and Newton (2013) the increased focus on the consumer and marketing initiatives to attract and retain business result in weak benchmarking and measurement methods. The aim of the study reported on in this article was to provide an easy-to-understand profitability equation for shopping centres and stand-alone outlets that will guide property management teams in their decision-making process.

A quantitative research design in which secondary data was collected was used in the study. A simple profitability formula was designed and applied to the raw data to convert it into useable numerical information (Creswell, 1994). The formula aims to enumerate the impact of quantifiable determinants on occupancy costs for different retail formats. The findings of the research are discussed in the following paragraphs.

\section{LITERATURE REVIEW}

A shopping experience is defined as successful if the intended shopping (utilitarian) and social (hedonic) goals were achieved (Batra \& Ahtola, 1990; Dhar \& Wertenbroch, 2000; Schechter, 1984). Retailers are thus encouraged not only to focus on their product offering, but also to ensure that the store destination is one that consumers would prefer above their competitors, whether they trade from a stand-alone outlet or a store within a shopping centre (Ellis, 1995).

\subsection{Retail format}

Both retail formats provide benefits to the consumer and the tenant, and it would be wise to occupy space in either of the two formats. The benefit of the stand-alone outlet is that the tenant maintains control over operational decisions while providing rewards for consumers focused on utilitarian goals (Brennan \& Lundsten, 2000; Ellis, 1995; Hira \& Mehvish, 2012; May, 1989; Paswan, Pineda \& Ramirez, 2010; Sayers, Low \& Davenport, 2008). The shopping centre environment, on the other hand, has the increased buying power from various anchor stores as well as entertainment areas that attract social shoppers to enjoy time away from home (Anderson, Narus \& Van Rossum, 2006; Bloemer \& Odekerken-Schroder, 2002; Burns \& Warren, 1995; Carpenter \& Moore, 2006; Donovan, Rossiter, Marcoolyn \& Nesdale, 1994; Hirschman \& Holbrook, 1982; Howard, 1997; Sayers, Low \& Davenport, 2008; Talpade \& Haynes, 1997).

As the preferences of consumers change, retailers and retail centres constantly have to evolve in their response in order to enhance their market position (Diep \& Sweeney, 2008; Hui, Yiu \& Yau, 2006). The positive relationship that exists between centre loyalty and store loyalty has an influence on the choice of retail centres that consumers frequent, and vice versa (Rabbanee, Ramaseshan, Wu \& Vinden, 2012). There are some consumers who evaluate the offering of a shopping centre solely on the perceived benefits they can gain from individual retailers within the centre (Salegna \& Goodwin, 2005). It can thus be deduced that the success of a centre is linked to the success of the retailer (Howard, 1997), which brings about additional considerations when retailers choose to trade in shopping centres.

The different tenant types within a shopping centre are fundamental to the success or failure of the centre and if space is allocated to these tenants optimally, the agglomeration of stores can ultimately benefit both landlords and tenants (0'Roarty, McGreal \& Adair, 1997); therefore, the maximisation of shopping centre profitability is attained by providing a mix of excellent services, good product offerings and a clean environment ( $\varepsilon l$ Hedhli, Chebat \& Sirgy, 2011; 0'Roarty et al., 1997; Yeates \& Montgomery, 1999). 
It is preferable when selecting a retail tenant mix that there should be one or more anchor tenants, food court operators and a diversity of mall stores. All these stores play a role in the micro retailing climate of a centre (Gerbich, 1998). The benefits of one-stop shopping are enjoyed only with the correct balance of assortment as well as the similarity of the retailers (Bean, Noon \& Ryan, 1987).

The model of shopping centre space allocation developed by Eppli and Shilling (1996) defined the distinction between anchor and non-anchor tenants. Anchor stores are most often large retail chain stores, and create drawing power for the centre by being the destination store (Kimball, 1991). The non-anchor tenant's benefit from the increased foot traffic by being located close to the anchor tenant (Eppli \& Shilling, 1996; Gerbich, 1998); thus it would be beneficial for a retailer that is not considered to be an anchor tenant to locate its premises as close to the 'destination' store as possible.

However, the mere inclusion of an anchor store is not sufficient; the type of anchor store is crucial. Retail tenant types have different externality generating abilities (Brueckner, 1993). This is the ability of a new store to drive feet to existing stores within a centre, thus creating cumulative attraction for the centre and consequently generating more business when the stores are located together than when they operate from separate locations (Bloemer \& Odekerken-Schroder, 2002; Brown, 1987).

The landlord's choice of tenant mix and allocation of space also influences the vacancy rate of a centre (Kirkup \& Rafiq, 1994). The vacancy rate is the percentage of vacant lettable area (vacant stores) over the total lettable (or leasable) area (Yeats \& Montgomery, 1999).

Being located in a shopping centre has some specific advantages and disadvantages. Increased security is the main advantage (Australian Government Productivity Commission, 2008), with long trading hours, strict rules set by landlords (Howard, 1997) and high rent listed as some of the main disadvantages of this format (Prendergast, Marr \& Jarratt, 1998).

Although it would be beneficial for the retailer to trade from either of these retail formats based on their target consumer market, one of the two formats would provide a better fit to the retailer's specific financial needs.

\subsection{Occupancy costs}

The financial implication of retail format choices relies on the occupancy cost of the trading space. Occupancy costs are the sum of all expenses that relate to the tenancy of a retail store (Crosby, Keogh \& Rees, 1992).

\subsection{Rent}

The value of rent forms the largest portion of the occupancy cost. Crosby et al. (1992) suggested that a basic understanding of typical lease terms is the start of the negotiation process to determine the value of rent. An additional clause, relating to turnover rent, is also commonly found in leases for retail commercial space (Wheaton, 2000).

As a formal structure, the rent portion of the lease agreement between the tenant and landlord covers four principal considerations: the deposit, the base rent, turnover rent and in some cases, tenant improvements (Benjamin \& Chinloy, 2004). Different external and internal factors 
determine the value of the rent and there are also different ways in which rent can be adjusted after the initial lease period, e.g. through rent reviews or renewals.

The security deposit is kept by the landlord and is a mechanism for landlords to protect themselves against the risk of tenant default and damages (Benjamin \& Chinloy, 2004).

The base rent value - payable monthly or annually - is fixed in year one and escalates annually at a specific increase as stipulated in the lease agreement (Benjamin \& Chinloy, 2004; Australian Government Productivity Commission, 2008). Base rents are either inclusive of all property costs (gross rent) or exclusive of some or all of the running costs of the property (net rent), with retail properties being more prone to net leases (Rowland, 1996).

Turnover rent is a unique feature of retail leasing and is a form of variable rent that is dependent on the business results of the tenant (Colwell \& Munneke, 1998; Hendershott \& Ward, 2003; Wheaton, 2000). The turnover or 'sales threshold rent' contingency provides the landlord with a share of sales that exceed a predetermined break point (Benjamin \& Chinloy, 2004). It would seem, as investigated by Wheaton (2000), that the sales revenue threshold for a turnover rent provision is expected to be relatively high, as turnover rent is usually included in exchange for lower base rent (Colwell \& Munneke, 1998; Wheaton, 2000). Tenants who pay less base rent tend to pay lower percentages of their sales as turnover rent; thus the inclusion of turnover rent does not automatically result in a higher percentage of turnover payable to the landlord (Wheaton, 2000).

From the viewpoint of the landlord, the inclusion of turnover rent in the lease agreement leads to superior returns when compared to leases with basic rent structures (Colwell \& Munneke, 1998; Hendershott, 2002). It also provides them with an incentive to manage the centre effectively and efficiently (Hendershott \& Ward, 2003; Pashigian \& Gould, 1998).

In addition to the financial benefits mentioned above, landlords view turnover rent contracts as an effective way to gather information, foster good relationships with tenants and act in the interest of their existing tenants (Addae-Dapaah \& Yeo, 1999; Benjamin \& Chinloy 2004; Hendershott, 2002; Hendershott \& Ward, 2003; Wheaton, 2000). Such turnover rent contracts can in turn be used to improve the tenant mix/location of the centre, which will ultimately benefit the tenants as well as the landlord.

However, turnover rent negotiations form only a minor aspect of the lease agreement, since various other determinants influence the decision of the final rent payment.

\subsection{Determinants of rent}

External factors that influence the value of rent include the return on the investment of the centre (Hutchison, Adair \& McWilliam, 2008; Jensen, 2008), the age (Gatzlaff, Sirmans \& Diskin, 1994; Jensen, 2008), the location (Gatzlaff et. al., 1994), and the size and accessibility of the centre (Sirmans \& Guidry, 1993; Tay, Lau \& Leung, 1996).

Other external factors that have an impact on the value of rent include tenant anchor status and externality generating abilities regardless of their location (Brueckner, 1993; Gerbich, 1998; Eppli \& Shilling, 1996) and the space allocation of these tenants (De Rosiers, Theriault \& Ozdilek, 2002; Eppli, Hendershott, Meija \& Shilling, 2000; Eppli \& Shilling 1996; Gerbich, 1998; Hutchinson, Adair \& McWilliam, 2008).

The status of the store is not the only influence on the value of rent: the size and performance of the anchor tenant store also directly influence the non-anchor tenants' sales and their ability to 
afford rent (Carter, 2009; Eppli \& Shilling, 1996; Gerbich, 1998). Hence, the rental bid is a function of potential consumer expenditure in a given location, potential market share and the quality of neighbouring tenants' space (Brueckner, 1993; Carter, 2009; 0'Roarty et al., 1997). The result is that stores that create greater externality pay a lower rent per unit of space (Brueckner, 1993; Carter, 2009).

A determinant that affects all tenants equally within a centre is the vacancy rate. Default risk of vacancy is found to be lower in shopping centres because the landlord is encouraged to secure a stable tenant mix and to spread the mix over a number of tenants (Hutchison et al., 2008; Kirkup \& Rafiq, 1994). Vacant space results in loss of rent in a two-step process: first, the loss of income for centre management and second, the possible required reduction in overall rent to retain remaining tenants (Killingsworth \& Farrow, 2007).

Attention is now given to internal factors that influence rent value and are controlled by either the tenant or the landlord and benefit either one or both of the parties involved.

Tenants are willing to pay higher premiums for prominently and conveniently located spaces within a centre (Tay, Lau \& Leung, 1996), accessibility by public transport (Tay, Lau \& Leung, 1996), size of the store in relation to the centre, and the actual size of the store (Gerbich, 1998; 0'Roarty et al., 1997; Wheaton, 2000). In the USA, tenants are less concerned about the actual rent passing than the relationship between rent and turnover (Hendershott, 2002).

The period of the lease, the responsibilities for operating expenses, statutory rights to renew the lease, statutory limits on rental increases, the basis of rent reviews, termination threats and many other provisions may influence the degree of risk transferred from the owners to their tenants in each country (0'Roarty et al., 1997; Tse, 1999). These are all factors that have an effect on the negotiation process when rent value is determined.

Leases are set in year one of occupancy, with unavoidable escalations - at least one future rent clause - in future years until the lease is either renewed or terminated (Eppli et al., 2000). These escalations are a way of protecting the landlord against the effects of inflation and changes in market rent value during the term of the lease (Reynolds \& Fetherstonhaugh, 2013).

From the discussion it can be concluded that the value of rent is determined not only by the actual leased space, but also by an array of external and internal factors that have an impact on the negotiation process. Ultimately, the relationship between the landlord and the tenant remains the key to a successful partnership and rent setting transactions (Addae-Dapaah \& Yeo, 1999; Crosby \& Murdoch, 2000).

\subsection{Other occupancy costs}

Various other costs that affect the retailer during the occupation of trading space are grouped together as 'other occupancy costs'. Shared expenses - often shared among tenants on the basis of Gross Lettable Area (GLA) - and variable expenses differ between different retail formats and can be directly or reasonably attributed to the operation, maintenance or repair of the building in which the retailer is located (Joo, Stoeberl \& Fitzer, 2009; Australian Government Productivity Commission, 2008).

Specifically for tenants that are located in shopping centres, additional costs are charged in the form of centre management fees, centre landscaping and maintenance of parking bays and other centre facilities (Australian Government Productivity Commission, 2008). 
Joo et al. (2009) found that improved management of total occupancy costs could influence and increase the profitability of a store. If these costs are understood, the tenant would be in a better position to negotiate on the value of rent, whether for a gross or net lease structure.

Very little research could be found to support the tenant's choice of retail format from a financial viewpoint; therefore the researcher aimed to provide retail management teams with some guidance regarding the financial implications of the two identified retail formats.

The researcher provided a logical order for management teams to follow when deciding on trading space. Specifically, the choice of retail format and the make-up of occupancy cost were identified as the two major influences that would guide management teams in making optimal decisions.

\section{RESEARCH METHODOLOGY}

The research was undertaken within a positivist paradigm by means of a quantitative research methodology, in an attempt to find an answer to the problem, namely that 'management neglects the impact of occupancy costs and resultant profitability of different retail formats when assessing expansion decisions'. Secondary data obtained from a single retailer was analysed using a simplified profitability formula. The simplified profitability formula was designed and applied to the raw data to convert it into useable numerical information (Creswell, 1994). This formula was used with the aim of calculating the impact of quantifiable determinants on occupancy costs for shopping centres and stand-alone outlets.

The researcher used the edited data to investigate the impact that size has on the value of the rent, both for individual stores and for format groupings. Thereafter, the researcher applied the results of the profitability formula to compare the profitability of the different retail formats. All the calculated amounts were approximated to a 'per size' basis in order to keep them comparable.

Once the initial analysis was completed, a time series analysis was performed in order to determine the trend of the retail format profitability over the five-year period under review.

\subsection{Research objectives}

The aim of the research was to provide financial guidance on occupancy costs and resultant profitability to guide management's approach regarding the financial implications when measuring and benchmarking between the two retail formats. To achieve the aim the following objectives were set:

- Establish whether size is a determinant of rent value for retail stores for the retailer selected.

- Explore the appropriateness of this size determinant of rent value when stores are grouped into shopping centre and stand-alone outlet formats.

- Compare the occupancy cost of stores within shopping centres and stand-alone outlets.

- Calculate and compare the profitability of stores within shopping centres and stand-alone outlets.

- Determine whether these results are consistent over a period of time.

0 ccupancy costs, which consist of rent and other operating expenses relating to the retail space, were used as a basis for the analysis. The lease terms, including size and location of the space as well as the retailer's externality generating abilities, were some of the determinants identified in 
the literature that had an impact on the value of rent. From the data available, the researcher could investigate the impact of the size determinant on the value of rent.

\subsection{Data}

The population comprised all retail stores in all retail formats in South Africa. In 2010 there were 1443 South African retail shopping centres and they consisted of various types and numbers of retail tenants (SACSC, 2010).

Data was obtained from a single retailer that had stores in both the stand-alone and shopping centre formats. In this manner sufficient data was obtained to support the comparability of the analysis between retail formats.

\section{TABLE 1: Number and average sizes of stores by format type}

\begin{tabular}{lcc}
\hline \multicolumn{1}{c}{ Retail format type } & Number of stores & Average size perstore $\left(\mathrm{m}^{2}\right)$ \\
\hline Neighbourhood centre & 3 & 4114 \\
Community centre & 4 & 5228 \\
Small regional centre & 14 & 5431 \\
Regional centre & 19 & 5527 \\
Value centre & 10 & 6237 \\
CBD stores & 5 & 6691 \\
Super regional centre & 6 & 7270 \\
Stand-alone outlet & 12 & 12649 \\
\hline
\end{tabular}

Source: Authors' analysis

Income statement data for each store was received for the financial periods ending in 2007 to 2011. This data provided details of the gross margin, the occupancy cost split between basic rent and other occupancy costs - and the size of each store.

The data used in the study was 'cleaned' to ensure that it was as consistent as possible for comparability reasons. Only leased, comparable stores (stores that had traded for the full fiveyear period) of the single selected retailer in South Africa were used in the study. These stores were then grouped into the different retail format categories.

\section{TABLE 2: Grouping of stores by retail format for sample}

\begin{tabular}{lcc}
\hline \multicolumn{1}{c}{ Retail format type } & Number of stores & Average size per store $\left(\mathrm{m}^{2}\right)$ \\
\hline Small shopping centres & 21 & 5204 \\
Large shopping centres & 35 & 6029 \\
Stand-alone outlets & 12 & 12649 \\
\hline
\end{tabular}

Source: Authors' analysis 
After completing the cleaning of the data as mentioned above, the final sample of the study consisted of 68 stores measured over a period of five years. This gave the researcher 340 scenarios from which to perform the analysis.

\subsection{Data analysis}

The researcher used five years' data as individual scenarios: firstly, because escalations could have affected the profitability of the store positively or negatively, and, secondly, to investigate any trends that may have emerged.

\subsubsection{Size}

The size refers to the gross lettable area in square metres for each store and from the literature reviewed the researcher was led to believe that the size of the store is negatively correlated to the value of rent of the store. Results for the individual stores as well as for the retail formats were compared.

A percentage-based cost and profit measure was considered; however, the actual value of these costs is easier to interpret.

\subsubsection{Occupancy costs}

Each store's income statement contains information relating to the basic rent paid as well as the other occupancy costs of the store. The literature shows that other occupancy costs included expenses like shared marketing expenses and centre management fees.

Due to the large proportion of rent in the total occupancy cost, it is analysed and compared separately.

Other occupancy costs are also expected to be higher in the shopping centre format due to the additional 'centre-related' charges added by landlords. The rand values of these costs were not useful in the study and were divided by the size to obtain a cost per square metre. Once these per square metre costs were calculated, they were compared to determine if the expectation of profit or loss had been met.

\subsubsection{Profitability}

As with any other profit-driven business, the profit of the operation is a key performance indicator of success in the retail environment. Profit is the net income left after all expenses have been deducted.

TABLE 3: Components of other occupancy costs

Other occupancy costs from data

Cleaning \& hygiene

Pest control

Refuse removal

Garden services 
Other occupancy costs from data

Operating costs:

Water

Rates and taxes

Security and alarms

Electricity

Source: Authors' analysis

For this study, the profitability model was adjusted slightly to be relevant to the data received. The formula was rewritten as follows:

Profitability = gross margin - occupancy costs

The calculation needs a source of income from which to deduct the costs. For this purpose, the gross margin of each store was obtained as part of the income statement data that was sourced.

The gross margin of a store is calculated by subtracting the cost of the goods sold from the selling price of the goods. The gross margins across the different retail formats are comparable due to a similar mix of merchandise that is sold at each store.

For the expense section of the adjusted profitability formula, the researcher also used the occupancy cost to reduce the income, as this is the only cost that was applicable in the current study.

\subsubsection{Time series}

A time series analysis based on the profitability of five years of shopping centres was compared to that of stand-alone outlets. This analysis assisted the researcher in guiding property managers on the selection of a retail format for one year and to confirm and strengthen the validity of the results over a longer period.

After the impact of size on the value of rent and resultant occupancy cost was established and the profitability of each format type was calculated and compared, the time series analysis was performed to confirm the results over a period of five years.

These results provided only a partial picture of total profitability when choosing an optimum retail format. The aim of this study was limited to the impact of the occupancy costs on these decisions. Other limitations that were identified are described next.

\subsection{Ethical considerations}

Due to the sensitivity of the data, permission from the retailer was required. All names of stores and locations were omitted in the analysis to protect the anonymity of the retailer. The researcher also signed a confidentiality agreement.

The researcher was not able to find a scholarly study that addressed the performance measures and benchmarking for different retail formats at the time of this study. Accordingly, this study was a first attempt in this area for South Africa. In addition, the use of internal data is unique to this study and anonymity of the company was maintained throughout the study. 
While there was the potential for breach of confidentiality in the work, all reasonable attempts were made to ensure total confidentiality.

\section{RESULTS}

The results are reported according to the objectives as set out in research methodology. First, the researcher aimed to establish whether size was a determinant of rent for individual stores as well as the appropriateness thereof for retail format types.

For the individual stores, the years 2007-2011 delivered a positive result for the relationship between size and rent. The expectation was that the relationship would be negative and thus the researcher initially rejected this relationship. After the stores were grouped into the three retail format types - small shopping centres, large shopping centres and stand-alone outlets - a positive relationship between size and rent value was also reported.

These results indicate that the format with the smallest average size per store, namely small shopping centres, also had the lowest rent per $\mathrm{m}^{2}$ and the stand-alone outlet with the largest average store size delivered the highest per $\mathrm{m}^{2}$ rent value in the years 2007-2011. Again, these results are consistent with the results of the positive relationship between size and rent for individual stores.

The next objective was to compare the occupancy cost of the stores within the different retail formats. Occupancy costs formed part of the components of the profitability model and the rand value per $\mathrm{m}^{2}$ as well as the percentage to sales was analysed. The occupancy costs consisted of rent and other occupancy expenses. From the contribution analysis as seen in TABLE 4, it is reported that the rent contributed the majority of the total occupancy costs across all retail format types.

TABLE 4: Rent contribution to total occupancy cost by retail format type

\begin{tabular}{lccccc}
\hline \multicolumn{5}{c}{ Rent contribution to total occupancy costs } \\
\hline & 2007 & 2008 & 2009 & 2010 & 2011 \\
Small shopping centre & $88.8 \%$ & $88.8 \%$ & $88.6 \%$ & $86.9 \%$ & $85.2 \%$ \\
Large shopping centre & $83.8 \%$ & $83.1 \%$ & $80.6 \%$ & $80.7 \%$ & $76.8 \%$ \\
Stand-alone outlet & $84.4 \%$ & $82.5 \%$ & $81.1 \%$ & $75.6 \%$ & $76.3 \%$ \\
\hline
\end{tabular}

Source: Authors' analysis

The rand value per $\mathrm{m}^{2}$ of the total occupancy costs as well as the percentage to sales was analysed. The results as seen in TABLE 5 indicated a similar result for the years 2007-2011 where the small shopping centre demanded the least amount of total occupancy costs and stand-alone outlets demanded the highest value per $\mathrm{m}^{2}$. 
TABLE 5: Total occupancy cost per $\mathbf{m}^{2}$

\begin{tabular}{lccccc}
\hline \multicolumn{5}{c}{ Total occupancy cost/ $m^{2}\left(R^{\prime} 000\right)$} \\
\hline Small shopping centre & 2007 & 2008 & 2009 & 2010 & 2011 \\
Large shopping centre & 614 & 675 & 721 & 769 & 813 \\
Stand-alone outlet & 715 & 813 & 931 & 980 & 1,007 \\
\hline
\end{tabular}

Source: Authors' analysis

The next measure applied to the analysis was the total occupancy cost as a percentage to sales. This ratio is however also influenced by the sales as generated by the format and would therefore be different from the initial results when based on $\mathrm{m}^{2}$.

TABLE 6: Total occupancy costs percentage to sales by retail format type

\begin{tabular}{llllll}
\hline \multicolumn{5}{c}{ Total occupancy cost \% to sales } \\
\hline Small shopping centre & 2007 & 2008 & 2009 & 2010 & 2011 \\
Large shopping centre & $3.5 \%$ & $3.5 \%$ & $3.7 \%$ & $3.6 \%$ & $3.5 \%$ \\
Stand-alone outlet & $3.7 \%$ & $3.8 \%$ & $4.2 \%$ & $4.0 \%$ & $3.9 \%$ \\
\hline
\end{tabular}

Source: Authors' analysis

TABLE 6 shows that the stand-alone outlet carried the least occupancy costs as a percentage to sales. This means that the stand-alone outlets incurred the least amount of occupancy costs per each rand of sales made. Next were small shopping centres, with the large shopping centres delivering the most expensive occupancy cost percentage to sales.

Due to the clearly identifiable components of total occupancy costs, the analysis was performed individually on the rent and other occupancy costs. The rent expense per $\mathrm{m}^{2}$ and the other occupancy cost per $\mathrm{m}^{2}$ are summarised in TABLE 7 .

The results shown in TABLE 7 indicate that both the rent and other occupancy costs for all retail format types increased gradually over the five-year period. 
TABLE 7: Summary of rent and other occupancy costs per $\mathbf{m}^{2}$ per store by retail format

\begin{tabular}{llccccc}
\hline & & \multicolumn{5}{c}{ Rent and other occupancy costs per $m^{2}$} \\
\hline \multirow{2}{*}{ Small shopping centre } & 2007 & 2008 & 2009 & 2010 & 2011 \\
& Rent & 545 & 599 & 639 & 668 & 692 \\
& Other OC & 69 & 76 & 82 & 101 & 121 \\
Large shopping centre & Rent & 600 & 676 & 751 & 790 & 773 \\
& Other OC & 116 & 137 & 181 & 190 & 234 \\
Stand-alone outlet & Rent & 980 & 984 & 975 & 926 & 1,007 \\
& Other OC & 181 & 209 & 228 & 299 & 313 \\
\hline
\end{tabular}

Source: Authors' analysis

* Other OC: Other occupancy costs

The stand-alone outlet format type still delivered the highest per $\mathrm{m}^{2}$ charge for both components of occupancy costs. The large shopping centre was less expensive than the stand-alone outlets, and the small shopping centre was found to be the least expensive.

The other approach, the percentage to sales, delivered contrasting results, as seen in TABLE 8.

TABLE 8: Summary of rent and other occupancy costs $\%$ to sales by retail format

\begin{tabular}{lllllll}
\hline & & \multicolumn{5}{c}{ Rent and other occupancy costs $\%$ to sales } \\
\hline \multirow{2}{*}{ Small shopping centre } & Rent & $3.1 \%$ & $3.1 \%$ & $3.3 \%$ & $3.1 \%$ & $3.0 \%$ \\
& Other OC & $3.5 \%$ & $3.5 \%$ & $3.7 \%$ & $3.6 \%$ & $3.5 \%$ \\
\hline Large shopping centre & Rent & $3.1 \%$ & $3.2 \%$ & $3.4 \%$ & $3.2 \%$ & $3.0 \%$ \\
& Other OC & $3.7 \%$ & $3.8 \%$ & $4.2 \%$ & $4.0 \%$ & $3.9 \%$ \\
\hline Stand-alone outlet & Rent & $2.0 \%$ & $1.9 \%$ & $1.7 \%$ & $1.6 \%$ & $1.6 \%$ \\
\hline
\end{tabular}

Source: Authors' analysis

* Other OC: Other occupancy costs

From the above analysis, it emerged that the stand-alone outlets were the least expensive in both the rent and other occupancy cost expenses as a percentage of sales, followed by small shopping centres and then large shopping centres. These findings gave an indication that the stand-alone outlet was the least expensive retail format, due to the low percentage expense per rand of sales results.

The total occupancy costs were analysed and used as input into the profitability model. The other leg of the profitability model, being the income component or the gross margin, also influenced the profitability of the retail formats. TABLE 9 was drawn to conclude on the per $\mathrm{m}^{2}$ analysis performed on this income component. 
TABLE 9: Gross margin per $\mathbf{m}^{2}$ by retail format type

\begin{tabular}{lccccc}
\hline \multicolumn{5}{c}{ Margin $/ \mathrm{m}^{2}$} \\
\hline & 2007 & 2008 & 2009 & 2010 & 2011 \\
Small shopping centre & 4,162 & 4,710 & 4,831 & 5,208 & 5,767 \\
Large shopping centre & 4,426 & 5,115 & 5,301 & 5,729 & 6,176 \\
Stand-alone outlet & 8,067 & 9,084 & 9,738 & 9,886 & 10,622 \\
\hline
\end{tabular}

Source: Authors' analysis

For all periods, stand-alone outlets delivered the optimum results, followed by the large shopping centres and lastly the small shopping centres; however, contrasting results on the percentage to sales analysis as per TABLE 10 were found.

These findings indicated that for all periods, small shopping centres delivered the highest results, followed by large shopping centres and lastly stand-alone outlets. Again, the amount of sales as well as the product mix in the different formats played a role in the outcome of this analysis.

TABLE 10: Gross margin \% by retail format type

\begin{tabular}{lccccc}
\hline \multicolumn{5}{c}{ Margin \% of sales } \\
\hline Small shopping centre & 2007 & 2008 & 2009 & 2010 & 2011 \\
Large shopping centre & $23.5 \%$ & $24.8 \%$ & $25.0 \%$ & $24.1 \%$ & $25.2 \%$ \\
\hline Stand-alone outlet & $22.7 \%$ & $23.9 \%$ & $23.9 \%$ & $23.3 \%$ & $24.1 \%$ \\
\hline
\end{tabular}

Source: Authors' analysis

The final analysis performed was that of the profitability of each retail format by combining the aforementioned results. This analysis was performed to compare the profitability of the different retail formats.

The profitability formula was performed on a rand per $\mathrm{m}^{2}$ basis as well as a percentage to sales basis. The following profitability formula was applied to the data to derive the results:

$$
\text { Profitability = gross margin }(a) \text { - occupancy costs }(b)
$$

TABLE 11 summarises the outcome of the rand value profitability per $\mathrm{m}^{2}$ of each of the retail format types over the five-year period. 
TABLE 11: Profitability per $\mathrm{m}^{2}$ by retail format type

\begin{tabular}{lccccc}
\hline & \multicolumn{5}{c}{ Profitability per m $^{2}$} \\
\hline & 2007 & 2008 & 2009 & 2010 & 2011 \\
Small shopping centre & 3,548 & 4,036 & 4,110 & 4,439 & 4,954 \\
Large shopping centre & 3,710 & 4,302 & 4,370 & 4,750 & 5,169 \\
Stand-alone outlet & 6,906 & 7,891 & 8,535 & 8,661 & 9,302 \\
\hline
\end{tabular}

Source: Authors' analysis

The results of the rand value profitability per $\mathrm{m}^{2}$ indicated that the stand-alone outlet was the most profitable retail format type across all years. In TABLE 12 the profitability as a percentage to sales is also summarised.

TABLE 12: Profitability percentage to sales by retail format type

\begin{tabular}{lccccc}
\hline \multicolumn{5}{c}{ Profitability $\%$ to sales } \\
\hline & 2007 & 2008 & 2009 & 2010 & 2011 \\
Small shopping centre & $20.0 \%$ & $21.2 \%$ & $21.2 \%$ & $20.5 \%$ & $21.6 \%$ \\
Large shopping centre & $19.1 \%$ & $20.1 \%$ & $19.7 \%$ & $19.3 \%$ & $20.2 \%$ \\
Stand-alone outlet & $14.4 \%$ & $14.9 \%$ & $14.8 \%$ & $14.6 \%$ & $14.6 \%$ \\
\hline
\end{tabular}

Source: Authors' analysis

The highest percentage in TABLE 12 indicates the best profitability as a percentage to sales. Based on these results, the small shopping centre is the most profitable retail format type. This format type is followed by the large shopping centre format, with the stand-alone outlet delivering the lowest profitability percentage to sales.

In summary, the results from the different approaches of the analyses were found to be conflicting, making it difficult to guide management teams in their choice of retail format when comparing financial data. It would be ideal for management teams to discuss the optimum profitability requirement with the finance department to determine which of the two measures, rand value or percentage to sales, is regarded as most important.

The results were similar across all of the years under review and are summarised in TABLE 13. The stand-alone outlet delivered the best results in the following categories: gross margin per $\mathrm{m}^{2}$, rent percentage to sales, other occupancy cost percentage to sales and overall profitability per $\mathrm{m}^{2}$.

The small shopping centre delivered the best results in the following categories: gross margin percentage to sales, rent per $\mathrm{m}^{2}$, other occupancy cost per $\mathrm{m}^{2}$ and overall profitability percentage to sales.

The large shopping centre format did not deliver optimum results in any of the analysed scenarios, indicating that the financial benefit from trading in this retail format type is not derived from the occupancy costs. 
TABLE 13: Summary of results by performance criterion

\begin{tabular}{cc}
\hline & Best performer \\
\hline Gross margin per $\mathrm{m}^{2}$ & Stand-alone outlet \\
Gross margin \% to sales & Small shopping centre \\
Rent per $\mathrm{m}^{2}$ & Small shopping centre \\
Rent \% to sales & Stand-alone outlet \\
Other occupation cost per $\mathrm{m}^{2}$ & Small shopping centre \\
Other occupation cost \% to sales & Stand-alone outlet \\
Profitability per $\mathrm{m}^{2}$ & Stand-alone outlet \\
Profitability \% to sales & Stand-alone outlet \\
\hline
\end{tabular}

Source: Authors' analysis

In summary, the researcher attempted to determine the impact of rent on profitability in order to provide financial guidance to property management teams when benchmarking different retail formats. This included an investigation into the relationship between size and rent value as well as a comparison of the profitability of different retail formats.

The expectation set by prior studies regarding the inverse relationship between the size and the rent value of a store was investigated. This relationship was rejected, as all periods indicated a positive relationship between size and rent. An adjusted profitability formula was applied to the data obtained, and was analysed by referring to the income and expense components separately. Gross margin was regarded as the income component of the formula and the total occupancy costs as the expense component.

In all scenarios, the rand values per $\mathrm{m}^{2}$ as well as the percentage to sales measure were applied to the data. These two measures delivered conflicting outcomes on most of the analyses performed, with stand-alone outlets and small shopping centres outperforming the large shopping centres. In the section that follows, the researcher provides guidance to property management teams based on the outcome as disclosed in this section.

\section{CONCLUSION}

Retailers' property management teams must well-informed of the preferences and needs of the consumers in the specific market in which they operate as well as of the financial influence the different formats might have on the bottom line of their retail businesses. The aim of the study was to provide an easy-to-understand profitability equation for shopping centres and standalone outlets that will guide retailers' property management teams in their decision-making process.

A survey of the relevant literature identified a number of factors that must be taken into account, namely the retail format, tenant mix and occupancy cost. Occupancy cost includes rent, shared expenses and variable expenses. Tenants in shopping centres have even more costs, such as centre management fees, centre landscaping, parking bay maintenance and other centre facilities. It is evident that the value of rent is determined not only by the actual leased space, but also by an 
array of external and internal factors that affect the task of a retailer's property management team. However, very little research could be found to support the tenant's choice of a retail format from a financial point of view; this indicated the need for guidance regarding the financial implications of the two identified retail formats.

This research introduced an easy-to-understand profitability equation when shopping centres and stand-alone outlets are compared. The profitability equation thus provides a methodology for retail property management teams to follow when deciding on trading space. Specific attention should be given to the two major influences that should guide retail property management teams in making optimal decisions, namely the selection of the retail format and the make-up of the occupancy cost.

Further research opportunities include the expansion of the profitability comparisons to other retail formats and a detailed analysis of the impact of anchor tenant status or externality generating abilities on occupancy costs in shopping centres. The economic impact on rental levels and occupancy costs could also be explored.

The outcome of the research provides retailers' property management teams with a tool to make informed decisions if they contemplate following Wal-Mart's move to a smaller retail format.

\section{LIST OF REFERENCES}

Addae-Dapaah, K. \& Yeo, C. (1999). Percentage lease agreement as a shopping centre management tool: a panacea for Singapore's retail industry woes? Property Management, 17:24-36.

Alexander, K. (2012). Challenges and opportunities: The Wal-Mart effect in South Africa. Unpublished (masters) thesis. Johannesburg: University of the Witwatersrand

Anderson, J.C., Narus, J.A. \& Van Rossum, W. (2006). Customer value propositions in business markets. Harvard Business Review, 84(3):91-99.

Australian Government Productivity Commission (2008). The market for retail tenancy leases in Australia. Productivity commission inquiry report no 43. March 2008. Available from http://www.pc.gov.au/_data/assets/pdf_file/0009/82746/retail-tenancy-market.pdf (Accessed: 14 June 2013).

Batra, R. \& Ahtola, 0.T. (1990). Measuring the hedonic and utilitarian sources of consumer attitude. Marketing letters 2(2):159-170.

Bean, J.C., Noon, C.E. \& Ryan, S.M. (1987). Selecting tenants in a shopping mall. The University of Michigan: Ann Arbor.

Benjamin, J.D. \& Chinloy, P. (2004). The structure of a retail lease. Journal of real estate research, 26(2):223-236.

Bloemer, J. \& Odekerken-Schroder, G. (2002). Store satisfaction and store loyalty explained by customer and store-related factors. Journal of Consumer Satisfaction, Dissatisfaction and Complaining Behavior, 15:68-80.

Brennan, D.P. \& Lundsten, L. (2000). Impacts of Large? International journal of retail distribution management, 30(8/9):394-406.

Brown, S. (1987). Institutional change in retailing: a review and synthesis. European journa/ of marketing, 21(6):181-206. 
Brueckner, J. (1993). Inter store externalities and space allocation in shopping centers. Journal of real estate research, $7(1): 5-17$.

Burns, D.J. \& Warren, H.B. (1995). Need for uniqueness: shopping mall preference and choice activity. International journal of retail distribution management, 23(12):4-12.

Carpenter, J.M. \& Moore, M. (2006). Consumer demographics, store attributes, and retail format choice in the US grocery market. International journal of retail and distribution management, 34(6):434-452.

Carter, C.C. (2009). What we know about shopping centers. Journal of Real Estate Literature, $17(2): 165-180$.

Colwell, P.F. \& Munneke, H.J. (1998). Percentage leases and the advantages of regional malls. Journal of real estate research, 15(3):239-252.

Creswell, J.W. (1994). Research Design: Qualitative \& Quantitative Approaches. London: SAGE Publications, 1994.

Crosby, N., Keogh, G. \& Rees, G. (1992). Methodology and convention in the standardization of retail rents. Journal of property valuation \& investment, 10(4):740-756.

Crosby, N. \& Murdoch, S. (2000). The influence of procedure on rent determination in the commercial property market of England and Wales. Journal of property investment \& finance, 18(4):420-444.

Deal, S. (6 January 2012). Retailers Breaking Out Departments Into Standalone Stores. Available from http://www.instoretrends.com/index.php/2012/01/06/retailers-breaking-out-departments-intostandalone-stores/ (Accessed: 4 April 2013).

De Rosiers, F., Theriault, M. \& Ozdilek, U. (2002). Shopping center rents and agg/omeration economies: preliminary findings from empirical evidence. Paper presented at the $9^{\text {th }}$ European Real Estate Society Conference, Glasgow, Scotland, June 4-7, 2002.

Dhar, R. \& Wertenbroch, K. (2000). Consumer choice between hedonic and utilitarian goods. Journal of Marketing Research, 37:60-71.

Diep, V.C.S. \& Sweeney, J.C. (2008). Shopping trip value: do stores and trip matter? Journal of retailing and consumer services, 15:399-409.

Donovan, R.J., Rossiter, J.R., Marcoolyn, G. \& Nesdale, A. (1994). Store atmosphere and purchasing behavior. Journal of retailing, 70(3):283-294.

El Hedhli, K., Chebat, J.C. \& Sirgy, M.J. (2011). Shopping well-being at the mall: Construct, antecedents, and consequences. Journal of business research, doi:10.1016/j.jbusres.2011.06.011.

Ellis, K. (1995). The determinants of the nature and types of customer-salesperson relationships in a retail setting: an empirical study. Doctoral dissertation. Tuscaloosa: The University of Alabama.

Eppli, M.J., Hendershott, P.H., Meija, L.C. \& Shilling, J.D. (2000). Lease overage rent clauses: motivation and use. American real estate society conference, Santa Barbara, CA, April, 2000.

Eppli, M.J. \& Shilling, J.D. (1996). How critical is a good location to a regional shopping centre? Journal of Real Estate Research, 12(3):459-469.

Gatzlaff, D.H., Sirmans, G.S. \& Diskin, B.A. (1994).The effect of anchor tenant loss on shopping center rents. Journal of Real Estate Research, 9:99-110.

Gerbich, M. (1998). Shopping center rentals: An empirical analysis of the retail tenant mix. Journal of real estate research, 15(3):283-296. 
Hendershott, P.H. (2002). A comparison of upward-only and turnover leases. Journal of property investment \& finance, 20(6):513-524.

Hendershott, P.H. \& Ward, C.W.R. (2003). Valuing and pricing retail leases with renewal and overage options. Journal of real estate finance and economics, 26(2/3):223-240.

Hira, F. \& Mehvish, R. (2012). Determining the factors affecting consumer loyalty towards shopping malls. Global advanced research journal of management and business studies, l(4):134-140.

Hirschman, E.C. \& Holbrook, M.B. (1982). Hedonic consumption: emerging concepts, methods and propositions. Journal of Marketing, 46(3):92-101.

Howard, દ. (1997). The management of shopping centers: Conflict or collaboration? The international review of retail, distribution and consumer research, 7(3) 263-285.

Hui, E.C.M., Yiu, C.Y. \& Yau, Y. (2006). Retail properties in Hong Kong: a rental analysis. Journal of property investment \& finance, 25(2):136-146.

Hutchison, N., Adair, A. \& McWilliam, J. (2008). Covenant strength in shopping centres: a diversified risk? Journal of property investment \& finance, 26(4):329-341.

Jensen, U. (2008). A framework for determining the factors influencing the performance of commercial property investments. Thesis. Johannesburg: University of Johannesburg.

Joo, S.J., Stoeberl, P.A. \& Fitzer, K. (2009). Measuring and benchmarking the performance of coffee stores for retail operations. Benchmarking: An International Journal, 16(6):741-753.

Killingsworth, R. \& Farrow, B. (2007). Adaptive reuse of large single-tenant retail facilities. The construction and building research conference of the Royal Institution of Chartered Surveyors.

Kimball, W.J. (1991). Recent trends in the shopping centre market. Appraisal Journal, 59(3):382-394.

Kirkup, M. \& Rafiq, M. (1994). Managing tenant mix in new shopping centers. International journal of retail and distribution management, 22(6):29-37.

May, દ.G. (1989). A retail odyssey. Journal of Retailing, 65(3):357-367.

Navarro, C. \& Ripsam, T. (2007). Big Impact In a Small Format: a new wave in retail. Available from http://www.booz.com/global/home/what-we-think/reports-white-papers/article-display/impactsmall-format (Accessed 30 May 2013).

O'Roarty, B., McGreal, S. \& Adair, A. (1997). The impact of retailer's store selection criteria on the estimation of retail rents. Journal of Property valuation and investment, 15(2):119-130.

Pashigian, B.P. \& Gould, E.D. (1998). Internalizing externalities: The pricing of space in shopping malls. Journal of Law and Economics, 4:115-142.

Paswan, A., Pineda, M.D.S. \& Ramirez, F.C.S. (2010). Small versus large retail stores in an emerging market - Mexico. Journal of business research, 63:667-672.

Prendergast, G., Marr, N. \& Jarratt, B. (1998). Retailers' view of shopping centres: a comparison of tenants and non-tenants. Journal of retail \& distribution management, 26(4):162-171.

Rabbanee, F.K., Ramaseshan, B., Wu, C. \& Vinden, A. (2012). Effects of store loyalty on shopping mall loyalty. Journal of Retailing and Consumer Services, 19:271-278.

Reynolds, K, \& Fetherstonhaugh, G. (2013). Handbook of rent review. London: Sweet \& Maxwell.

Rowland, P.J. (1996). Comparing net with gross rents. Journal of property valuation \& investment, $14(3): 20-32$. 
SACSC (South African Council of Shopping Centres) (2010). Southern African shopping centre directory. 2010 Edition.

Salegna, G.J. \& Goodwin, S.A. (2005). Consumer loyalty to service providers: an integrated conceptual model. Journal of Consumer Satisfaction, Dissatisfaction and Complaining behavior, 18:51-67.

Sayers, J., Low, W. \& Davenport, દ. (2008). Te Warewhare: The impact of The Warehouse on Maori in Kaitaia, Kerikeri and Motueka. The University of Auckland Business Review, 10(2):35-43.

Schechter, L. (1984). A normative conception of value. Progressive Grocer, Executive Report.

Sirmans, C.F. \& Guidry, K.A. (1993). The determinants of shopping centre rents. The Journal of Real Estate Research, 8:107-115.

Talpade, S. \& Haynes, J. (1997). Consumer shopping behavior in malls with large scale entertainment centers. Mid-Atlantic Journal of business, 33:153-162 (June).

Tay, R.S., Lau, C.K. \& Leung, M.S. (1996). The determination of rent in shopping centers: Some evidence from Hong Kong. Journal of real estate literature, 7(2):183-196.

Jennings, D. \& Newton, R. The Equal Partners: Customer and supplier alignment in office occupancy. Available from http://www.businessvantage.co.uk/downloads/ EP3Final\%20version\%20-\%20SUMMARY.pdf (Accessed: 20 June 2013)

Tse, R. (1999). Lag vacancy, effective rents and optimal lease term. Journal of property investment \& finance, $17(1): 75-88$.

Wheaton, W. C. (2000). Percentage rent in retail leasing: the alignment of landlord - tenant interest. Real Estate Economics, 28(2):185-204.

Yeates, M. \& Montgomery, D. (1999). The changing commercial urban centres and vacancy rates structure of non-metropolitan. The Canadian Geographer, 43(4):382-399. 